90 | Penerapan Undang-Undang Nomor 35 Tahun 2014

\title{
Penerapan Undang-Undang Nomor 35 Tahun 2014 Tentang Perlindungan Anak dalam kaitannya Tindak Pidana Penyalahgunaan Narkoba Oleh Anak di Bawah Umur
}

\author{
Nur Aisyah \\ Institut Agama Islam Negeri (IAIN) Bone \\ nuraisyahhtniainbone@gmail.com
}

\begin{abstract}
Abstrak
Kajian dalam penelitian ini adalah bentuk-bentuk perlindungan hukum terhadap anak yang menyalahgunakan narkoba, pemberian hak anak yang dipidana serta pelaksanaan Undang-Undang Nomor 35 Tahun 2014 Tentang Perlindungan Anak di Polres Bone. Hasil penelitian menunjukkan bahwa pelaksanaan Undang-Undang Nomor 35 Tahun 2014 Tentang Perlindungan Anak telah terealisasi di Polres Bone, karena dimana anak yang terlibat dengan kasus penyalagunaan narkoba betul-betul mendapatkan perlindungan hukum dari pemerintah, dimana pihak Kepolisian Polres Bone tetap memberikan hak-hak anak yang menjadi tersangka. Anak tetap mendapatkan pendidikan bagi yang masih sekolah. Bagi anak yang putus sekolah akan di berikan kesempatan untuk mengembangkan ide serta kekreatifannya pada suatu instansi yang bekerja sama dengan pihak Polres Bone. Proses pemeriksaan yang dilakukan oleh anak akan didampingan oleh orang tua serta penasehat hukum. Anak yang terbukti telah menggunakan narkoba akan diberikan pengobatan berupa rehabilitasi hingga anak dikategorikan bebas dari narkoba. Dengan kebijakan yang diberikan oleh pihak Kepolisian Polres Bone, maka anak yang telah di kategorikan sebagai pengguna bisa bersosialisasi kembali dengan masyarakat dengan baik.
\end{abstract}

Kata Kunci : Undang-Undang Nomor 35 Tahun 2014, Perlindungan Anak dalam kaitannya Tindak Pidana Penyalahgunaan Narkoba Oleh Anak di Bawah Umur

\section{PENDAHULUAN}

Meningkatnya kualitas sumber daya manusia di Indonesia, telah menjadikan modal utama yang sangat penting untuk berkompetensi di era globalisasi pada saat ini. Dalam suatu lingkungan, anggota masyarakat yang satu dengan masyarakat yang lainnya sering kali melakukan perubahan pergaulan, sehingga perubahan pergaulan tersebut menimbulkan peristiwa atau kejadian yang sifatnya melawan hukum. ${ }^{110}$

Salah satu peristiwa tersebut adalah penyalahgunaan narkoba yang semakin

\footnotetext{
${ }^{110}$ Rika saraswati, Hukum Perlindungan Anak di Indonesia, (Cet. I; Bandung: PT. Citra Aditya Bakti, 2009), h. 111.
} 
meningkat setiap tahunnya dan meresahkan banyak masyarakat. Karena Pelaku penyalahgunaan narkoba atau orang yang menggunakan narkoba tanpa hak tidak memandang usia, karena bukan hanya orang dewasa tetapi tidak lain berasal dari golongan remaja dan anak-anak di bawah umur. ${ }^{111}$

Usia anak-anak merupakan sasaran untuk mendapatkan pengaruh negatif, karena usia anak-anak merupakan masa pencarian identitas diri, saat dimana anak-anak mulai muncul rasa ingin tahu, rasa penasaran dan rasa ingin mencoba berbagai hal baru dan bahkan berisiko tinggi. Oleh karena itu, sangat mungkin jika semakin hari semakin bertambah jumlah tindak pidana penyalahgunaan narkoba dikalangan anak-anak. ${ }^{112}$

Anak sebagai generasi muda merupakan penerus bangsa, awal yang penting dalam upaya menyiapkan masa depan negara. Baik buruknya masa depan bangsa tergantung pula pada baik buruknya kondisi anak saat ini. Berkaitan dengan hal tersebut, maka perlakuan terhadap anak dengan cara yang baik adalah kewajiban kita bersama, agar ia bisa tumbuh berkembang dengan baik dan dapat menjadi pengembang risalah peradaban bangsa ini. ${ }^{113}$

Apabila anak kurang mendapatkan perhatian dari lingkungan terdekat maka mudah baginya untuk melakukan perbuatan yang menyimpang dari norma hukum yang berlaku di masyarakat, untuk itu perkembangan anak harus memenuhi hak-hak dan kewajiban anak. ${ }^{114}$

Hak-hak anak di Indonesia diatur secara khusus dalam Undang-Undang

\footnotetext{
${ }^{111}$ Lydia Harliina Martono, Satya joewana, Membantu Pemulihan Pecandu Narkoba dan Keluarganya, (Cet. I; Jakarta: Balai Pustaka, 2005), h. 2

${ }^{112}$ As'aril Muhajir, Ilmu Pendidikan Perspektif Kontekstual, (Cet. III; Jogjakarta: Ar-ruzz Media, 2016), h. 113.

${ }^{113}$ M. Nasir Djamil, Anak Bukan Untuk Dihukum, (Cet. II; Jakarta: Sinar Grafika, 2013), h.11.

${ }^{114}$ M. Nasir Djamil, Anak Bukan Untuk Dihukum, h. 11. 
92 | Penerapan Undang-Undang Nomor 35 Tahun 2014

Nomor 35 Tahun 2014 tentang perubahan atas Undang-Undang Nomor 23 Tahun 2002 tentang Perlindungan Anak. Dalam Pasal 1 ayat 12, Undang-Undang Nomor 23 Tahun 2002 tentang Perlindungan Anak disebutkan bahwa anak adalah bagian dari hak asasi manusia yang wajib dijamin, dilindungi, dan dipenuhi oleh orang tua, keluarga, masyarakat, pemerintahan dan negara. ${ }^{115}$ Kewajiban seorang anak bukan semata-mata hanya sebagai beban, tetapi justru dengan melakukan kewajiban-kewajiban anak tersebut berpredikat. ${ }^{116}$

Jika semua hak dan kewajiban anak telah terlaksanakan dengan baik, maka sangat minim untuk terciptanya suatu peristiwa yang melawan hukum terhadap anakanak. Tetapi hak dan kewajiban tersebut semakin hari semakin tak terlaksanakan, sehingga semakin banyak anak-anak yang bermasalah dengan hukum.

Permasalahan yang menjadi perhatian saat ini adalah kasus narkoba, Kabupaten Bone menjadi perhatian pemerintah khusus Badan Narkotika Nasional dalam melindungi anak terlibat narkoba. Kepala Badan Narkotika nasional Kabupaten Bone, Muharram Sahude menyatakan bahwa pihaknya selalu berusaha melakukan pencegahan serta pemberantasan penggunaan Narkoba, karena Penyalahgunaan narkoba di Kabupaten Bone meningkat pada tahun 2014-2016. Pada tahun 2014 terdiri atas 36 kasus dan 57 orang yang menjadi tersangka, pada tahun 2015 naik menjadi 47 kasus dan ditetapkan 75 tersangka dan meningkat lagi pada awal tahun 2016 dengan jumlah kasus 59 dan 86 orang menjadi tersangka. Tahun 2017 sampai dengan September, jumlahnya mulai menurun terdiri 46 kasus dengan tersangka sebanyak 55 orang. ${ }^{117}$ Yang menjadi pusat perhatian dalam penemuan kasus narkoba yaitu adanya

\footnotetext{
${ }^{115}$ M. Nasir Djamil, Anak Bukan Untuk Dihukum, h. 12.

${ }^{116}$ M. Nasir Djamil, Anak Bukan Untuk Dihukum, h. 21.

117 www. Boneposnarkotika.com, diases 22 november 2017

Jurnal Al-Dustur; VOLUME 2 NO 1, JUNI 2019
} 
salah seorang anak berusia 13 tahun yang terlibat dalam kasus penyalahgunaan narkoba yang berdomisili di Jalan Mangga, Kabupaten Bone. Yang menjadi pengguna dan sekarang telah direhab di Rumah Sakit Hapsah, karena usia yang masih dibawah umurlah yang menjadi penyesalan bagi petugas Badan Narkotika Nasional (BNN) pada saat menemukan pengguna narkoba. ${ }^{118}$

Seorang anak yang terlibat dalam kasus narkoba akan mendapatkan perlindungan hukum, seperti yang dijelaskan dalam Undang-Undang No. 35 Tahun 2014 tentang Perlindungan Anak, Pasal 59 ayat (2 e) bahwa: "Perlindungan khusus kepada anak sebagaimana dimaksud pada ayat (1) diberikan kepada anak yang menjadi korban penyalahgunaan narkotika, alkohol, psikotropika, dan zat adiktif lainnya." 119 Yang masuk dalam golongan anak di bahwah umur yaitu anak yang masih berusia 12 sampai 18 tahun, dimana anak dibawah umur tersebut berhak mendapatkan bantuan hukum apabila melakukan kesalahan yang sifatnya melawan hukum. Pihak Balai Pemasyarakatan (BAPAS) seringkali menggunakan Undang-Undang Nomor 35 Tahun 2014 Pasal $76 \mathrm{C}$ tentang Perlindungan Anak dalam membantu anak di bawah umur yang terlibat kasus narkoba, dimana isi dari pasal tersebut yaitu: Setiap orang dilarang menempatkan, membiarkan, melakukan, menyuruh melakukan, atau turut serta melakukan kekerasan terhadap anak. ${ }^{120}$

Seperti penjelasan Undang-Undang tersebut haruslah terealisasi, tetapi pada kenyataannya di Kabupaten Bone, belum terealisasi secara menyeluruh sesuai dengan peraturan perundang-undangan yang berlaku. Karena dimana pada kenyataannya pada

\footnotetext{
${ }^{118}$ Muharram Sahude, dikutip dari hasil wawancara ketua Badan Narkotika Nasional, (11 Desember 2017, pukul 11.00 wita).

${ }^{119}$ UU No. 35 Tahun 2014 tentang Perlindungan Anak.

${ }^{120}$ A. Masjaya, Dikutip dari hasil wawancara Staf Balai Pemasyarakatan Kabupaten Bone, (tanggal 28 desember 2017, pukul 10.40 wita) 
94 | Penerapan Undang-Undang Nomor 35 Tahun 2014

akhir tahun 2017 masih ada anak di bawah umur yang di pidana dengan kasus penyalahgunaan narkoba. $^{121}$

Perlindungan seseorang dalam kasus narkoba akan selalu berbeda dalam pemberian perlindungan hukum, dan jika seorang anak yang masih dibawah umur harus lebih mendapatkan perlindungan dan pembinaan hukum. Dalam UUD 1945 pasal 28 ayat 1 sampai 10 menjelaskan tentang Hak Asasi Manusia, dimana semua masyarakat sama dimata hukum (equality before of the law) dan berhak mendapatkan bantuan, dan begitu pula seorang anak yang terlibat persoalan hukum akan lebih mendapatkan bantuan hukum, karena bantuan yang terkhusus untuk anak telah dijelaskan dalam Undang-Undang No. 35 Tahun 2014 tentang Perlindungan Anak, yang menjamin terpenuhinya hak-hak anak sesuai harkat dan martabat kemanusian serta mendapatkan perlindungan dari tindak kekerasan dan diskriminasi. ${ }^{122}$

Seorang anak yang terlibat dalam kasus narkoba, menjadi permasalahan utama karena dimana adanya seorang anak yang di pidanakan, Sehingga permasalahan ini mendorong penulis untuk membuat skripsi dengan judul:"Penerapan UndangUndang Nomor 35 Tahun 2014 tentang Perlindungan Anak dalam kaitannya Tindak Pidana Penyalahgunaan Narkoba Terhadap Anak di Bawah Umur."

Berawal dari latar belakang di atas maka penulis menarik kesimpulan rumusan masalah yaitu Bagaimana efektifitas dari pelaksanaan Undang-Undang Nomor 35 Tahun 2014 tentang Perlindungan Anak dalam tindak pidana penyalahgunaan narkoba terhadap anak dibawah umur di Polres Bone dan Bagaimana bentuk perlindungan hukum terhadap anak di bawah umur dalam perkara tindak pidana penyalagunaan

\footnotetext{
${ }^{121}$ A. Masjaya, Dikutip dari hasil wawancara Staf Balai Pemasyarakatan Kabupaten Bone, (tanggal 28 desember 2017, pukul 10.40 wita)

${ }^{122}$ Rika saraswati, Hukum Perlindunagn Anak di Indonesia, h. 113. Jurnal Al-Dustur; VOLUME 2 NO 1, JUNI 2019
} 
narkoba .

\section{TINJAUAN PUSTAKA}

Salah satu syarat yang harus dipenuhi seorang penulis untuk menunjukkan keasliannya suatu penelitian yang dilakukan yaitu menegaskan letak perbedaan penelitiannya dengan hasil-hasil penelitian sebelumnya yang sejenis dengan penelitian yang dilakukan. Karena merupakan suatu keharusan bagi setiap penelitian untuk melakukan penelusuran terhadap hasil-hasil penelitian dan bukan plagiarisme.

Adapun hasil penelusuran terkait hasil-hasil penelitian terdahulu yang sejenis dengan penelitian yang akan dilakukan ini, antara lain:

Muskifah, Sekolah Tinggi Agama Islam Negeri Watampone "Upanya Pemerintah Dalam Menanggulangi Tindak Pidana Narkoba (Analisis Hukum Terhadap Pelaksanaan Undang-Undang Nomor 35 Tahun 2009 Tentang Narkoba)”. Upaya pemerintah dalam menanggulangi tindak pidana narkoba bagi kehidupan masyarakat, bangsa dan negara tidak hanya dapat dipecahkan melalui aspek hukum semata, melainkan juga harus dipecahkan melalui aspek lingkungan kesehatan, pendidikan, sosial dan budaya. Kerena efek yang ditimbulkan dapat merusak sistem fungsi otak dan jiwa. Untuk mengetahui keefektifitasnya haruslah senantiasa berpedoman kepada Undang-Undang Nomor 35 Tahun 2009 tentang Narkotika. ${ }^{123}$

Baso Darmawangsa, Sekolah Tinggi Agama Islam Negeri Watampone "Urgensi Pendidikan Islam Dalam Mengantisipasi Bahanya Penyalangunaan Narkoba Terhadap Kehidupan Anak Di Kecamatan Tempe Kabupaten Wajo.”

${ }^{123}$ Muskifa, "Upanya Pemerintah Dalam Menangulangi Tindak Pidana Narkoba (Analisis Hukum Terhadap Pelaksanaan Undang-Undang Nomor 35 Tahun 2009 Tentang Narkoba)”, (Skripsi, Program Sarjana Sekolah Tinggi Agama Islam Negeri, Watampone, 2013). 
Pendidikan Islam merupakan usaha yang mengarahkan anak senantiasa memiliki sikap mental yang sesuai dengan kehendak Allah SWT. Pelaksanaan pendidikan Islam di lingkungan masyarakat diharapkan mampu mengantisipasi bahaya narkoba tersebut, karena orang yang memahami dan menghayati pendidikan Islam baik itu orang yang sudah dewasa dan bahkan anak yang masih kecil. Maka mereka mampu mengimplementasikannya dalam kehidupan sehari-hari sehingga tidak akan pernah terkontaminasi dengan penyalahgunaan obat-obat terlarang atau narkoba. ${ }^{124}$

M. Yarham Samad, fakultas hukum Universitas Hasanuddin Makassar "(Tinjauan Yuridis Terhadap Pemidanaan Bagi Anak Dalam Tindak Pidana Penyalahgunaan Narkotika (Studi Kasus Putusan Nomor: 1109/Pid. B/2013/PN. Mks). " Secara hukum negara Indonesia telah memberikan perlindungan kepada anak melalui berbagai aturan hukum, dalam kasus narkotika seorang anak yang terlibat akan mendapatkan bantuan hukum, sehingga seorang anak tidak dapat dipidanakan dengan alasan-alasan tertentu atau jika seorang anak dihukum akan berbeda dengan orang dewasa. ${ }^{125}$

Dari deskripsi di atas nampak bahwa masalah yang akan penulis bahas mengenai tinjauan yuridis normatif, terkait penerapan Undang-Undang No. 35 Tahun 2014 tentang Perlindugan Anak, dalam kaitannya Tindak Pidana Penyalahgunaan Narkoba Terhadap Anak dibawah Umur.

\footnotetext{
${ }^{124}$ Baso Darmawangsa, "Urgensi Pendidikan Islam Dalam Mengantisipasi Bahanya Penyalangunaan Narkoba Terhadap Kehidupan Anak Di Kecamatan Tempe Kabupaten Wajo”, (Skripsi, Program Sarjana Sekolah Tinggi Agama Islam Negeri, Watampone, 2008).

${ }^{125}$ M. Yarham samad, Search Skripsi Lengkap Pidana. Diakses pada halam websate, https://www.google.co.id/search skripsi lengkap pidana, (hari jumat, 13 Oktober 2017, pukul 10.30 wita) Jurnal Al-Dustur; VOLUME 2 NO 1, JUNI 2019
} 


\section{METODE PENELITIAN}

Kata metode berasal dari kata bahasa Yunani methodos,terdiri dari dua kata yaitu meta berarti menuju, melalui, dan mengikuti, sedangkan hodos berarti jalan, cara dan arah. Jadi arti kata methodos adalah metode ilmiah yaitu cara melakukan sesuatu menurut aturan tertentu. ${ }^{126}$ Sudah diketahui bersama bahwa di dalam penulisan suatu karya ilmiah harus di topang oleh metode baik dari pengumpulan data maupun dari cara pengelolaannya. Seperti penyusunan skripsi ini dipergunakan metode sebagai berikut:

\section{Jenis dan Pendekatan Penelitian}

a. Jenis penelitian

Jenis penelitian ini adalah penelitian lapangan (Field Research). Penelitian lapangan (Field Research) adalah suatu penelitian yang menghasilkan data-data yang bersifat deskriptif-analitis, yaitu apa yang dinyatakan oleh responden secara tertulis atau lisan dan perilakunya secara nyata, serta hal yang diteliti dan dipelajari sebagai sesuatu yang utuh. ${ }^{127}$ Deskriptif yaitu bahwa penelitian ini dilakukan dengan melukiskan objek penelitian berdasarkan peraturan perundang-undangan dan bertujuan memberikan gambaran sesuatu objek yang menjadi masalah dalam penelitian. Data yang diperoleh dari hasil pengamatan, wawancara, dokumentasi, analisis, catatan lapangan, disusun peneliti di lokasi penelitian, bukan dalam bentuk angka. Hasil analisis datanya berupa pemaparan yang berkenaan

\footnotetext{
${ }^{126}$ Juliansyah Noor, Metodologi Penelitian, (Cet. IV; Jakarta: Kencana, 2014), h. 22

${ }^{127}$ Soerjono Soekanto, Pengantar Penelitian Hukum (Cet. III; Jakarta: UI-Press, 1986), h. 32. Jurnal Al-Dustur; VOLUME 2 NO 1, JUNI 2019
} 
98 | Penerapan Undang-Undang Nomor 35 Tahun 2014

dengan situasi yang diteliti dan disajikan dalam bentuk cerita. ${ }^{128}$

b. Pendekatan penelitian

Penelitian yang dilakukan oleh penulis menggunakan pendekatan yaitu:

1) Yuridis normatif adalah penelitian yang mengacu pada norma hukum yang terdapat dalam peraturan perundang-undangan dan putusan pengadilan serta norma-norma yang hidup dan berkembang dalam masyarakat. ${ }^{129}$

2) Yuridis Empiris adalah penelitian yang dilakukan dengan pendekatan pada realitas hukum dalam masyarakat. ${ }^{130}$

Kedua pendekatan di atas digunakan untuk menggambarkan bagaimana perlindungan hukum terhadap anak dibawah umur yang menjadi korban penyalahgunaan narkoba sesuai dengan Undang-Undang Nomor 35 Tahun 2014 tentang Perlindungan Anak.

\section{Lokasi Penelitian}

Adapun lokasi penelitian yang menyangkut dengan masalah yang diteliti oleh penulis adalah Polres Bone yang terletak di Jl. Laksamana Yos Sudarso di Kabupaten Bone, Provinsi Sulawesi Selatan. Alasan penulis memilih lokasi tersebut karena penulis tertarik untuk mengkaji tentang penerapan UndangUndang Nomor 35 Tahun 2014 tentang Pelindungan Anak, dalam kaitannya Tindak Pidana Penyalahgunaan Narkoba Terhadap Anak dibawah Umur.

\section{Data dan Sumber Data}

\footnotetext{
${ }^{128}$ Ismail Keri, Metodologi Penelitian dan Penulisan Karya Ilmiah ([t. c]; [t. tp]: Unit Jurnal dan Penerbitan STAIN Watampone, 2017), h. 13-14.

${ }^{129}$ Zainuddin Ali, Metode Penelitian Hukum, Ed. 1 (Cet.V; Jakarta: Sinar Grafika, 2014), h. 105.

${ }^{130}$ Syahruddin Nawawi, Penelitian Hukum Normatif Versus Penelitian Hukum Normatif (Cet. II; Makassar: PT Umotoha Ukhuwah Grafika, 2014), h. 8. 
Data kualitatif adalah data yang diperoleh dari berbagai sumber data. ${ }^{131}$ Data kualitatif digunakan dalam Data dan Sumber data dalam penelitian adalah subjek dari mana data diperoleh. ${ }^{132}$ Adapun jenis data yang diperlukan dalam penelitian ini meliputi data primer dan data sekunder. Kedua data tersebut didapatkan melalui sumber tertentu, yakni:

a. Data primer

Data primer adalah data yang diperoleh langsung pada subjek sebagai sumber informasi yang ingin di capai. ${ }^{133}$ Baik pribadi maupun dari suatu instansi yang mengelolah data untuk keperluan penelitian, seperti dengan melakukan wawancara secara langsung dengan pihak-pihak yang berhubungan dengan penelitian yang di lakukan.

b. Data sekunder

Data sekunder merupakan data yang diperoleh dari pihak lain, yakni tidak langsung diperoleh oleh peneliti dari subjek penelitiannya. Jenis data yang diperoleh melalui hasil pengolahan pihak kedua dari hasil penelitian lapangannya. ${ }^{134}$ Data sekunder berasal dari dokumentasi dan tinjauan pustaka seperti dokumen-dokumen resmi, buku-buku, hasil penelitian yang berwujud laporan.

\section{Instrumen Penelitian}

Instrumen penelitian menunjuk pada berbagai peralatan yang digunakan

${ }^{131}$ Sugiono, Memahami Penelitian Kualitatif, (Cet.VIII; Bandung: Alfabeta, 2013), h. 87.

${ }^{132}$ Suharsimi Arikunto, Prosedur Penelitian Suatu Pendekatan Praktek, Ed. Revisi, (Cet. XII; Jakarta: PT Rineka Cipta, 2002), h. 107.

${ }^{133}$ Abdullah K, Tahapan dan Langkah-langkah dalam Penelitian, (Cet. I; Watampone: Lukman Al Hakim Press, 2013), h. 41.

${ }^{134}$ Burhan Bungin, Metode Penelitian Kualitatif, (Cet. VIII; Jakarta: Raja Grafindo, 2011), h. 155.

Jurnal Al-Dustur; VOLUME 2 NO 1, JUNI 2019 
selama melakukan penelitian. Instrumen adalah mekanisme untuk mengukur suatu fenomena yang digunakan untuk mengumpulkan dan mencatat informasi untuk penelitian, pengambilan keputusan, dan akhirnya memahami fenomena tersebut. ${ }^{135}$ Dalam penelitian ini penulis menggunakan instrumen:

a. Dalam metode observasi maka instrument yang digunakan adalah cek list, dan kamera.

b. Dalam metode wawancara maka instrumen yang digunakan penulis adalah tape recorder, metode wawancara, dan lain-lain.

5. Teknik Pengumpulan Data

Dalam penelitian ini penulis akan menggunakan beberapa teknik pengumpulan data yaitu:

a. Observasi dapat diartikan sebagai pengamatan dan pencatatan secara sistematika terhadap unsur-unsur yang tampak dalam suatu gejala pada objek penelitian. ${ }^{136}$

b. Wawancara merupakan suatu proses atau dialog secara lisan antara pewancara dan responden dengan tujuan untuk memperoleh informasi yang dibutuhkan oleh peneliti. ${ }^{137}$

c. Dokumentasi merupakan suatu cara pengumpulan data yang dilakukan dengan menganalisis isi dokumen yang berhubungan dengan masalah yang diteliti. Metode ini digunakan untuk mengumpulkan data yang sudah tersedia

h. 112 .

${ }^{135}$ Nanang Martono, Metode Penelitian Sosial, (Cet. I; Depok: PT Raja Grafindo Persada,2015),

${ }^{136}$ S. Eko Putro Widoyoko, Teknik Penyusunan Instrumen, (Cet. I; Yogyakarta: Pustaka Pelajar, 2012), h. 46.

${ }^{137}$ S. Eko Putro Widoyoko, Teknik Penyusunan Instrumen, h. 40. Jurnal Al-Dustur; VOLUME 2 NO 1, JUNI 2019 
dalam catatan dokumen, seperti konsep teori yang berkaitan dengan variabel yang diteliti. ${ }^{138}$

6. Teknik Analisis Data

Dalam menganalisis data, penulis menggunakan analisis data secara kualitatif, analisis data kualitatif adalah penelitian yang berupaya menganalisis kehidupan sosial menggambarkan dunia sosial dari sudut pandang atau interpretasi individu (informasi) dalam latar alamiah. Dengan kata lain penelitian kualitatif berupaya menjelaskan bagaimana seorang individu, menggambarkan, atau memaknai dunia sosialnya. Analisis data secara kualitatif dengan tahapan sebagai berikut:

a. Pengumpulan data lapangan yakni dengan mengumpulkan data yang ditemukan dilapangan yang merupakan data kasar.

b. Reduksi data adalah proses memilih atau menyederhanakan, mengabstraksikan dan mentranspormasikan data kasar yang baru dari lapangan.

c. Penyajian data merupakan sekumpulan informasi yang tersusun secara sistematis yang kemungkinan adanya penarikan kesimpulan.

d. Verifikasi data yakni penarikan kesimpulan akhir penelitian. ${ }^{139}$

\section{HASIL PENELITIAN DAN PEMBAHASAN}

${ }^{138}$ S. Eko Putro Widoyoko, Teknik Penyusunan Instrumen, h. 49.

${ }^{139}$ Muhammad Tholchah Hasan, dkk. Metode Penelitian Kualitatif Tinjauan Teoritis dan Praktis (Cet. III; Surabaya: Visipress Media, 2009), h. 183. 


\section{Penerapan Undang-Undang Nomor 35 Tahun 2014 tentang Perlindungan Anak dalam Tindak Pidana Penyalahgunaan Narkoba Terhadap Anak di Bawah Umur}

1. Pelaksanaan Undang-Undang Nomor 35 Tahun 2014 tentang Perlindungan Anak dalam Tindak Pidana Penyalahgunaan Narkoba Terhadap anak di Bawah Umur di Polres Bone

Penyelesaian perkara-perkara pidana anak dapat diselesaikan dengan perspektif perlindungan terhadap anak, namun di sisi lain proses penegak hukum tidak bisa melanggar aturan yang telah di tetapkan dalam UndangUndang tersendiri. Terdapat beberapa bentuk perlindungan anak yang di jelaskan dalam Undang-Undang Nomor 35 Tahun 2014 Tentang Perlindungan Anak.

Perkembangan penyalahgunaan narkoba semakin hari semakin meningkat, pemerintah telah menerbitkan aturan yang mengatur tentang penanganan anak yang menjadi pelaku tindak pidana penyalahgunaan narkoba yaitu Undang-Undang Republik Indonesia Nomor 35 Tahun 2009 Tentang Narkotika. Sedangkan Anak yang menjadi pelaku tindak pidana atau kejahatan diatur dalam Undang-Undang Republik Indonesia Nomor 11 Tahun 2012 Tentang Sistem Peradilan Pidana Anak, sedangkan anak sebagi korban diatur dalam Undang-Undang Republik Indonesia Nomor 35 Tahun 2014 Tentang perubahan Undang-Undang Republik Indonesia Nomor 23 Tahun 2002 Tentang Perlindungan Anak.

Setiap tindak pidana yang dilakukan oleh anak akan diselesaikan dengan melalui proses peradilan yang dilakukan di Pengadilan Negeri, dimana proses penyelesaiannya menggunakan mekanisme yang berbeda dari pengadilan pada umumnya. Dalam hal ini proses persidangan anak dilakukan dengan cara yang berbeda dengan persidangan orang dewasa, hakim melakukan persidangan ditempat yang berbeda dengan proses yang berbeda pula dari pada yang sering kita jumpai di pengadilan pada umumnya. Hal ini guna untuk 
memberikan rasa nyaman kepada anak dan tidak menimbulkan tekanan kepada anak. $^{140}$

Hal ini di jelaskan dalam Undang-Undang Nomor 11 Tahun2012 Tentang Sistem Peradilan Pidana Anak Bahwa:

\section{Pasal 53}

(1) Anak disidangkan dalam ruang sidang khusus anak,

(2) Ruang tunggu sidang anak dipisahkan dari ruang tunggu sidang orang dewasa,

(3) Waktu sidang anak didahulukan dari waktu sidang orang dewasa.

\section{Pasal 54}

Hakim memeriksa perkara anak dalam sidang yang dinyatakan tertutup untuk umum, kecuali pembacaan putusan. ${ }^{141}$

Penanganan anak yang menghadapi masalah hukum terutama penyalahgunaan narkotika oleh anak harus mengutamakan atau memprioritaskan kepentingan yang terbaik untuk anak tersebut. Anak wajib dilindungi agar tidak menjadi korban baik secara langsung maupun secara tidak langsung. Dalam hal ini yang dimaksud korban dalam penyalahgunaan narkotika adalah anak-anak yang mengalami kerugian baik secara mental, fisik maupun sosial disebabkan oleh tindakan orang atau sekelompok orang.

Banyaknya peristiwa hukum mengenai penyalahgunaan narkoba sehingga terjadi beberapa hambatan untuk meminimalisir pengguna narkoba khususnya anak yang masih di bawah umur. Seperti diketahui bahwa di Kabupaten Bone tingkat penyalahgunaan narkoba semakin meningkat dan bahkan anak harus jadi sasaran untuk meningkatkan kejahatan tersebut, dengan cara menjadikan anak sebagai alat pencobaan untuk menggunakan narkoba.

${ }^{140}$ Ilham Labaruna, Hasil wawancara penyedik pembantu Bintara SatuanReserse Narkoba Polres Bone, (tanggal 14 juli 2018, pukul 10.45 Wita)

${ }^{141}$ Undang-Undang Nomor 11 Tahun 2012 tentang Sistem Peradilan Pidana Anak Jurnal Al-Dustur; VOLUME 2 NO 1, JUNI 2019 
Orang yang menggunakan narkoba pada awalnya hanya coba-coba, muncul rasa yang ingin tahu narkoba itu seperti apa, yang pada akhirnya ketergantungan dengan obat tersebut. Karena narkoba memiliki efek yang pada akhirnya pengguna bisa kecanduan. Pengguna narkoba khususnya anak yang masih dibawah umur ini biasanya terjadi karena faktor lingkungan dimana keadaan keluarga yang berantakan, misalnya orang tua yang cerai dan pada akhirnya anak yang menjadi korban akibat perceraian tersebut. ${ }^{142}$

Seorang anak yang memiliki keluarga yang terpecah belah seperti itu, memiliki kemudahan untuk mencoba segala hal karena anak kurang mendapatkan pengawasan dari keluarga. Sehingga beberapa anak di Kabupaten Bone pada akhirnya terungkap bahwa telah menggunakan narkoba.

Kasus penyalahgunaan narkoba merupakan kasus yang semakin meningkat dari tahun ketahun dari hasil penangkapan oleh pihak Polres Bone, adapun data kasus Narkotika selama 3 Tahun terakhir terhitung mulai dari 2015 s/d 2017 yang di tangani oleh polres Bone :

\begin{tabular}{|c|c|c|c|c|l|}
\hline Tahun & $\begin{array}{c}\text { Kasus } \\
\text { Narkoba }\end{array}$ & $\begin{array}{c}\text { Jumlah } \\
\text { Tersangka }\end{array}$ & $\begin{array}{c}\text { Pengguna } \\
\text { Dewasa }\end{array}$ & $\begin{array}{c}\text { Pengguna } \\
\text { Anak }\end{array}$ & Ket. \\
\hline 2015 & 47 & 75 & 70 & 5 & \\
\hline 2016 & 60 & 88 & 86 & 2 & \\
\hline 2017 & 62 & 88 & 83 & 5 & \\
\hline Jumlah & $\mathbf{1 6 9}$ & $\mathbf{2 5 1}$ & $\mathbf{2 3 9}$ & $\mathbf{1 2}$ & \\
\hline
\end{tabular}

Sumbr Data : Polres Bone Tahun 2018

Berdasarkan table diatas penulis dapat menggambarkan bahwa selama

3 (tiga) Tahun terakhir, kasus tindak pidana penyalahgunaan narkoba di Polres Bone berjumlah 169 kasus, tersangka jumlah 251 Orang, pengguna dewasa

${ }^{142}$ Ilham Labaruna, Hasil wawancara penyedik pembantu Bintara SatuanReserse Narkoba Polres Bone, (tanggal 14 juli 2018, pukul 10.45 Wita) 
berjumlah 239 Orang, dan pengguna anak berjumlah 12 Orang. Dari tahun 2015 s/d 2017 terlihat jelas bahwa setiap tahunnya jumlah kasus selalu mengalami peningkatan, seperti pada Tahun 2015 sebanyak 47 kasus, tersangka berjumlah 75 orang, pengguna dewasa berjumlah 70 orang sedangkan pengguna anak berjumlah 5 orang. Pada tahun 2016 sebanyak 60 kasus, tersangka berjumlah 88 orang, pengguna dewasa berjumlah 86 orang dan pengguna anak berjumlah 2 orang. Dan pada Tahun 2017 sebanyak 62 kasus, tersangka berjumlah 88 orang, pengguna dewasa berjumlah 83 orang, dan pengguna anak berjumlah 5 orang. ${ }^{143}$

Jumlah kasus yang di tangani oleh pihak kepolisian Polres Bone kebanyakan dari laporan masyarakat. Dalam artian tidak serta merta setelah laporan diterima, tersangka langsung di tahan. Pihak kepolisian Polres Bone tetap melakukan proses penyidikan apakah laporan itu benar adanya.

Hasil dari penangkapan pihak Polres Bone mengungkapkan bahwa dari sekian pengguna yang di temukan, hanya jenis narkoba sabu yang di gunakan dengan kata lain yaitu jenis narkoba Metanfetamina, terkait dengan anak yang menjadi pengguna narkoba juga biasanya menggunakan obat keras yaitu Termadol, dimana obat ini juga memberikan efek yang ketergantungan. ${ }^{144}$

Undang-Undang Nomor 35 Tahun 2014 Tentang Perlindungan Anak, Pasal 9 ayat (1) menyatakan bahwa "Setiap anak berhak memperoleh pendidikan dan pengajaran dalam rangka pengembangan pribadinya dan tingkat kecerdasannya sesuai dengan minat dan bakat."145

Undang-undang tersebut telah menjelaskan bahwa anak perlu mendapatkan pendidikan, dan kebijakan yang di lakukan oleh pihak Polres

\footnotetext{
143 Arya Dwiyanto, Hasil wawancara administrasi Urbin Obs Sat Res Narkoba Polres Bone, (tanggal 31 Juli 2018, pukul 10.20 Wita).

144 Ilham Labaruna, Hasil wawancara penyedik pembantu Bintara SatuanReserse Narkoba Polres Bone, (tanggal 14 juli 2018, pukul 10.45 Wita)

${ }^{145}$ Undang-Undang Nomor 35 Tahun 2014 tentang Perlindungan Anak.

Jurnal Al-Dustur; VOLUME 2 NO 1, JUNI 2019
} 
Bone telah merealisasikan undang-undang tersebut. Dimana anak yang di pidana yang masih dalam masa pendidikan akan terus melanjutkan pendidikannya, dimana anak yang akan melakukan Ujian Akhir akan diberikan kebijakan untuk mengikuti ujian tersebut dengan cara melakukan pengawalan kepada tersangka untuk menjalankan proses ujian. ${ }^{146}$

Anak yang di pidana dengan kasus penyalahgunaan narkoba berharap mendapatkan keadilan dari putusan hakim dalam proses persidangan, karena diamana keadilan itu merupakan kebijakan politik yang aturan-aturannya menjadi dasar dari peraturan Negara. ${ }^{147}$ Dengan adanya kebijakan maka hakhak dan perlindungan hukum akan di dapatkan oleh anak yang di pidana.

Dalam Undang-Undang Nomor 11 Tahun 2012 Tentang Sistem Peradilan Pidana Anak Pasal 71 bahwa:

(1) Pidana pokok bagi anak terdiri atas:

a.Pidana peringatan,

b.Pidana dengan dengan syarat:

1) Pembinaan diluar lembaga

2) Pelayanan masyarakat, atau

3) Pengawasan.

c.Pelatihan kerja,

d.Pembinaan dalam lembaga, dan

e.Penjara.

(2) Pidana tambahan terdiri atas:

a.Perampasan keuntungan yang diperoleh dari tindak pidana, atau b.Pemenuhan kewajiban adat.

\footnotetext{
${ }^{146}$ Hanny Willem, Hasil wawancara penyedik Kanit Sidik SAT RES Narkoba polres Bone, (tanggal 14 Juli 2018, pukul 10.35 Wita)

${ }^{147}$ Siswanto Sunarso, filsafat hukum pidana ,Ed.1(Cet.1; Jakarta: Rajawali Pers, 2015), h. 264 Jurnal Al-Dustur; VOLUME 2 NO 1, JUNI 2019
} 
(3) Apabila dalam hukum materiil diancam pidana kumulatif berupa penjara dan denda, pidana denda diganti dengan pelatihan kerja,

(4) Pidana yang dijatuhi kepada anak dilarang melanggar harkat dan martabat anak,

(5) Ketentuan lebih lanjut mengenai bentuk dan tata cara pelaksanaan pidana sebagaimana dimaksud pada ayat (1), ayat (2), dan ayat (3) diatur dengan peraturan pemerintah. ${ }^{148}$

2. Kendala Polres Bone dalam menangani kasus penyalahgunaan narkoba

Penanganan kasus penyalahgunaan narkoba oleh pihak Polres Bone tentu memiliki beberapa kendala, mengingat bahwa pada saat ini bukan hanya orang dewasa yang menggunakan narkoba tersebut tetapi anak juga sudah terlibat dengan kasus narkoba. Maka muncul beberapa kendala yang di hadapi oleh pihak Polres Bone dalam menangani kasus penyalahgunaan narkoba oleh anak khususnya bagian Satuan Reserse Narkoba yaitu:

a. Kurangnya kesadaran dari pihak keluarga untuk melaporkan anaknya kepada pihak yang berwajib untuk dilakukan pengobatan medis untuk anaknya yang menggunakan narkoba, karena dimana orang Bone sangat menjunjung tinggi harga diri (siri) sehingga orang tua lebih memilih untuk diam melihak kelakuan anaknya. ${ }^{149}$

b. Terlalu cepat waktu dan masa penanganan kasus khusus anak yang menyalahgunakan narkoba.

c. Pada proses penyidikan pihak keluarga seakan menutupi kejahatan yang telah di lakukan oleh anaknya sebagai pengguna, dan selalu mengelak tentang apa yang telah anaknya lakukan dengan alasan bahwa anaknya tidak

${ }^{148}$ Undang-Undang Nomor 11 Tahun 2012 tentang Sistem Peradilan Pidana Anak

${ }^{149}$ Ilham Labaruna, Hasil wawancara penyedik pembantu Bintara SatuanReserse Narkoba Polres Bone, (tanggal 14 juli 2018, pukul 10.45 Wita) 
akan melakukan hal seperti itu karena anaknya masih usia dini dan tidak mungkin untuk melakukan pekerjaan seperti itu.

d. Tidak adanya pihak keluarga yang bisa di hubungi ketika ditemukan anak yang menggunakan narkoba di luar kota Kabupaten Bone.

e. Tidak adanya tempat penahanan khusus anak yang disediakan di polres Bone, sehingga anak yang masih di ambil keterangannya harus di titip di dalam ruangan hingga terbukti jenis perkara yang dilakukan. ${ }^{150}$ Karena tempat penahanan anak dan orang dewasa itu sebenarnya berbeda.

\section{Bentuk Perlindungan Hukum Terhadap Anak di Bawah Umur dalam Perkara Tindak Pidana Penyalahgunaan Narkoba}

Anak sebagai korban kejahatan khususnya penyalahguna narkoba, perlu mendapatkan perlindungan hukum karena mengingat bahwa psikologi seorang anak sangat lemah, untuk menghindari trauma yang di alami oleh anak perlu dilakukan beberapa upaya agar anak yang telah terlibat dengan narkoba bisa menjalankan kembali aktifitas kesehariannya dengan normal seperti biasa.

Memberikan hak-hak yang pantas kepada tersangka pidana merupakan perlindungan terhadap harkat manusia, sehingga jaminan pemerintah terhadap pelaksanaan hak tersangka tersebut sudah masuk ke wilayah peradaban umat manusia. Dalam hal ini, hukum dalam dunia yang beradab yaitu hukum yang antara lain melindungi hak-hak tersangka secara maksimal, diantaranya adalah atas suatu proses hukum yang adil. ${ }^{151}$

Upaya perlindungan hukum yang di berikan oleh aparat penegak hukum kepada anak yang menyalahgunakan narkoba, yaitu ketika dalam proses penangkapan terlebih dahulu di jelaskan tentang hak-hak anak itu seperti apa, di

\footnotetext{
${ }^{150}$ Hanny Willem, Hasil wawancara penyedik Kanit Sidik SAT RES Narkoa polres Bone, (tanggal 14 Juli 2018, pukul 10.35 Wita)

${ }^{151}$ Munir Faudy, Sylvia Laura L. Faudy,Hak asasi tersangka pidana, ( Cet. 1; Jakarta: Prenada Media Group, 2015), h. 1. 
jelaskan mulai dari pemeriksaan, proses penangkapan, penyidikan sampai seterusnya. Pada saat pemerikasaan anak berhak untuk di dampingi oleh orang tua dan penasehat hukum. Penasehat hukum ini wajib dan ditentukan oleh pihak Polres Bone dengan cara menyurat terlebih dahulu kepada pihak LBH dan menyurat ke kantor Bapas watampone serta Dinas kesejahteraan Sosial. Pihak yang telah di berikan kewenangan yang melakukan pemeriksaan kepada anak yang menyalahgunakan narkoba dan sebagai hasil akhir di tulis di berkas perkara dan dikirim ke Kejaksaan Bone untuk menindak lanjuti kasus tersebut. ${ }^{152}$

Hal ini sudah dijelaskan dalam Undang-Undang Nomor 11 Tahun 2012 Tentang Sistem Peradilan Pidana Anak Pasal 55 bahwa:

(1) Dalam sidang Anak, Hakim wajib memerintahkan orang tua/Wali atau pendamping, Advokat atau pemberi bantuan hukum lainnya, dan Pembimbing Kemasyarakatan untuk mendampingi Anak,

(2) Dalam hal orang tua/Wali dan/atau pendampingan tidak hadir, sidang tetap dilanjutkan dengan didampingi Advokat atau pemberi bantuan hukum lainnya dan/atau Pembimbing Kemasyarakatan,

(3) Dalam hal Hakim tidak melaksanakan ketentuan sebagaimana dimaksud pada ayat (2), sidang Anak batal demi hukum.

Anak yang masih dibawah umur yang menggunakan narkoba tetap akan dilakukan penahanan layaknya orang dewasa, orang yang menyalahgunakan narkoba sebenarnya proses hukumannya sama. Hal yang membedakan antara anak dengan orang dewasa hanyalah waktu penahanannya dimana anak lebih di berikan keringanan. ${ }^{153}$

Hak-hak tersangka pidana sangat penting untuk dilindungi oleh hukum. Tersangka biasanya adalah merupakan pihak yang diambil sebagai kemerdekaan

\footnotetext{
${ }^{152}$ Ilham Labaruna, Hasil wawancara penyedik pembantu Bintara SatuanReserse Narkoba Polres Bone, (tanggal 14 juli 2018, pukul 10.45 Wita)

${ }^{153}$ Hanny Willem, Hasil wawancara penyedik Kanit Sidik SAT RES Narkoa polres Bone, (tanggal 14 Juli 2018, pukul 10.35 Wita)

Jurnal Al-Dustur; VOLUME 2 NO 1, JUNI 2019
} 
pribadinya, misalnya dia ditangkap, ditahan, disita barangnya, dan sebagainya. Padahal hak-hak seperti itu merupakan hak yang sangat penting bagi seseorang. Karena itu hukum perlu benar-benar menjamin dan mengawasi agar pengambilan hak tersangka tersebut tidak dilakukan secara sewenang-wenagn atau secara berlebih-lebihan. ${ }^{154}$

Terkait dengan pembagian tugas dan wewenang sub bagian yang ada di Polres Bone dalam menangani kasus penyalahgunaan narkoba sebenarnya kinerjanya semua sama, yang diberikan tugas untuk kasus narkoba akan bekerja sama untuk menyelesaikan tugas tersebut terkusus di bagian satuan reserse narkoba dan selalu melakukan sosialisasi dengan masyarakat yang ada di kabupaten bone untuk memberantas kasus narkoba. ${ }^{155}$

Perlindungan yang diberikan oleh pemerinta kepada anak yang dalam situasi darurat adalah perlindungan khusus sebagaimana yang diatur dalam Undang-Undang Nomor 35 Tahun 2015 Tentang Perlindungan Anak dalam Pasal 59 sebagai berikut:

2) Pemerintah, pemerintah daerah, dan lembaga Negara lainnya berkewajiban dan bertanggung jawab untuk memberikan perlindungan khusus kepada anak.

3) Perlindungan khusus kepada anak sebagaimana dimaksud pada ayat (1) diberikan kepada:
a. Anak dalam situasi darurat,
b. Anak yang berhadapan dengan hukum,
c. Anak dari kelompok minoritas dan terisoolasi,
d. Anak yang dieksploitasi secara ekonomi dan/atau seksual,

${ }^{154}$ Munir Faudy, Sylvia Laura L. Faudy, Hak asasi tersangka pidana, h. 7

${ }^{155}$ Hanny Willem, Hasil wawancara penyedik Kanit Sidik SAT RES Narkoa polres Bone, (tanggal 14 Juli 2018, pukul 10.35 Wita)

Jurnal Al-Dustur; VOLUME 2 NO 1, JUNI 2019 
e. Anak yang menjadi korban penyalahgunaan narkoba, alcohol, psikotropika, dan zat adiktif lainnya,

f. Anak yang menjadi korban pornografi,

g. Anak dengan HIV/AIDS,

h. Anak korban penculikan, penjualan, dan/atau perdagangan,

i. Anak korban kekerasan fisik dan/atau psikis,

j. Anak korban kejahatan seksual,

k. Anak korban jaringan terorisme,

1. Anak penyandang disabilitas,

m. Anak korban perlakuan salah dan penelantaran,

n. Anak dengan perilaku sosial mnimpang, dan

o. Anak yang menjadi korban stigmatisasi dari pelabelan terkait dengan kondisi orang tuanya. ${ }^{156}$

Anak yang terlibat dengan kasus narkoba memiliki ketentuan khusus untuk mendapatkan perlindungan hukum, seperti yang telah dikemukakan oleh anggota Polres Bona, tergantung dari perannya apakah anak tersebut sebagai pengedar atau penyalahguna. Mengenai anak sebagai pegedar maka anak tersebut akan di proses hukum dan akan dilakukan penahan, waktu penahanan untuk anak yang sebagai pengedar tergantung dari kejaatan yang dilakukannya. Berbeda dengan pengguna bahwa anak yang menggunakan narkoba akan tetap di proses dan di lakukan penahanan, akan tetapi agak sedikit berbeda dengan pengedar. Karena anak yang menggunakan narkoba bisa mendapatkan proses rehabilitasi, berbeda sebagai pengedar hanya akan mendapatan proses penahanan. ${ }^{157}$

Relevan dengan pelindungan anak yang menjadi pelaku, dalam UndangUndang Nomor 35 Tahun 2009 Tentang Narkotika, mengatur tentang pengobatan

${ }^{156}$ Undang-Undang Nomor 35 Tahun 2014 tentang Perlindungan Anak.

${ }^{157}$ Hanny Willem, Hasil wawancara penyedik Kanit Sidik SAT RES Narkoa polres Bone, (tanggal 14 Juli 2018, pukul 10.35 Wita)

Jurnal Al-Dustur; VOLUME 2 NO 1, JUNI 2019 
dan rehabilitasi pada Pasal 53 sampai dengan Pasal 59. Proses rehabilitasi memiliki dua jenis yaitu rehabilitasi medis dan rehabilitasi sosial. Rehabitasi medis berupa detoksifikasi, intoksifisikasi, rawat jalan, penanganan penyakit komplikasi dampak buruk narkotika, psikoterapi, penanganan dual diagnosis, voluntary counseling and testing (VCT). Sedangkan rehabilitasi sosial berupa program bimbingan kerohanian, bimbingan mental dan spiritual, serta kepramukaan. ${ }^{158}$

Undang-Undang Nomor 35 Tahun 2009 Tentang Narkotika pada Pasal 54 menyatakan bahwa pecandu narkoba dan korban penyalahgunaan narkoba wajib menjalani proses rehabilitasi medis dan reabilitasi sosial. ${ }^{159}$ Maka tidak ada alasan bagi pengguna narkoba untuk tidak melakukan proses pengobatan.

Bagi penyalahguna narkoba di Kabupaten Bone memiliki tempat khusus untuk proses rehabilitasi medis, di mana bagi penyalahguna narkoba yang masih di kategorikan pemula proses rehabilitasinya di lakukan RS Hapsah Jl. Urip Sumoharjo No.10, Kelurahan Mattirowalie, Kec. Tanete Riattang Barat, Kabupaten Bone. Sedangkan bagi orang yang telah di kategorikan sebagai pecandu narkoba maka dilakukan di Balai Rehabilitasi BNN Baddoka Jl. Batara Bira, Pai, Biring Kanaya, Kota Makassar, SulSel. ${ }^{160}$ Untuk mengetahui bahwa orang yang menggunakan narkoba bisa di kategorikan sebagai pemula dan pecandu, tentu telah dilakukan tes urien terlebih dahulu yang di lakukan oleh dokter yang telah bekerja sama dengan pihak kepolisian.

Anak yang di anggap telah menggunakan narkoba akan di lakukan pemeriksaan oleh dokter untuk memastikan hasilnya seperti apa, jika pada tes urien yang dilakukan mengatakan bahwa hasilnya negatif (-) maka anak tersebut hanya melakukan proses rehab jalan dimana anak wajib untuk di periksa di BNN selama

\footnotetext{
${ }^{158}$ Ilham Labaruna, Hasil wawancara penyedik pembantu Bintara SatuanReserse Narkoba Polres Bone, (tanggal 14 juli 2018, pukul 10.45 Wita)

${ }^{159}$ Undang-Undang Nomor 5 Tahnu 2009 Tentang Narkotika.

${ }^{160}$ Ilham Labaruna, Hasil wawancara penyedik pembantu Bintara SatuanReserse Narkoba Polres Bone, (tanggal 14 juli 2018, pukul 10.45 Wita) 
2 X 1 minggu. Jika anak dikategorikan sebagai pemula, maka dilakukan proses rehabilitasi di RS Hapsah Watampone. Waktu penahanannya selama 2 (dua) minggu, selama menjalani proses rehabilitasi di Rumah Sakit maka anak di wajibkan untuk tinggal di Rumah sakit tersebut. Berbeda bagi orang pengguna yang dikategorikan sebagai pecandu, proses rehabilitasinya di lakukan di Balai Rehabilitasi BNN Baddoka Makassar paling cepat 3 (tiga) bulan. Untuk mendaptkan proses rehabilitasi yang maksimal maka proses rehabilitasinya pada bulan pertama maka tidak dilakukan pembesukan, ketika menjelang 2(dua) bulan barulah di izinkan pihak keluarga untuk membesuk. ${ }^{161}$

Adapun jenis reabilitasi medis yang di dapatkan oleh anak dibawah umur di RS Hapsah yaitu setiap harinya diberikan makanan bergizi untuk kelancaran pemulihan anak tersebut, dan diberikan obat secara teratur serta pemeriksaan kesehatan secara teratur, serta di lakukan proses medis asesmen. ${ }^{162}$ Sedangkan yang melakukan rehabilitasi sosial akan di tempatkan di Dinas Kesejateraan Sosial atau di UPTD LLK UKM Watampone untuk melakukan pelatihan kerja guna mengembangkan kekreatifan anak. ${ }^{163}$ Dijelaskan dalam Undang-Undang Nomor 11 Tahun 2012 Tentang Sistem Peradilan Pidana Anak pada Pasal 78 bahwa:

(1) Pidana pelatihan kerja sebagaimana dimaksud dalam Pasal 71 ayat (1) huruf c dilaksanakan di lembaga yang melaksanakan pelatihan kerja yang sesuai dengan usia anak,

(2) Pidana pelatihan kerja sebagaimana dimaksud pada ayat (1) dikenakan paling singkat 3 (tiga) bulan dan paling lama 1(satu) tahun.

Dari pembahasan diatas maka penulis dapat menyimpulkan bahwa pihak kepolisian Polres Bone dalam memberikan perlindungan hukum terhadap anak

\footnotetext{
${ }^{161}$ Ilham Labaruna, Hasil wawancara penyedik pembantu Bintara SatuanReserse Narkoba Polres Bone, (tanggal 14 juli 2018, pukul 10.45 Wita)

162 M.R, Hasil wawancara anak penyalahguna narkoba, (tanggal 20 Juli 2018, pukul 11.00 Wita.

${ }^{163}$ Ilham Labaruna, Hasil wawancara penyedik pembantu Bintara SatuanReserse Narkoba Polres Bone, (tanggal 14 juli 2018, pukul 10.45 Wita)
} 
yang menyalahgunakan narkoba cukup efektif dan efisian, walaupun dalam hal ini semua bentuk perlindungan anak belum tercapai, tetapi sampai saat ini beberapa bentuk perlindungan yang di berikan kepada anak sangat memberikan efek positive pada anak yang pernah dikategorikan penyalahguna narkoba. Dalam proses penahanan anak dibawah umur, pihak kepolisian Polres Bone memberikan perlindungan hukum kepada anak seperti yang di jelaskan dalam Undang-Undang Nomor 35 Tahun 2014 Tentang Perlindungan anak. Serta pemberian hak kepada penyalahguna narkoba untuk dilakukan pengobatan berupa proses rehabilitasi yang di jelaskan dalam Undang-Undang Nomor 35 Tahun 2009 Tentang Narkotika.

\section{PENUTUP}

Berdasarkan pada uraian dalam pembahasan, maka peneliti dapat membuat kesimpulan bahwa :

1. Penerapan Undang-Undang Nomor 35 Taun 21014 Tentang Perlindungan Anak di Polres Bone belum sepenunya terlaksana secara efektif hal ini disebabkan adanya beberapa faktor. Peranan anak sebagai penyalahguna narkoba terjadi karena berasal dari anak itu sendiri, tingginya rasa ingin tahu anak, rasa penasaran untuk mencoba. Hal ini terjadi karena kurangnya pengawasan dari orang tua, namun dalam hal ini dari pihak Kepolisian Polres Bone selalu berusaha untuk memberikan pelayanan secara maksimal kepada anak, bahwa anak perlu untuk dilindungi karena anak merupakan penerus bangsa. Anak yang dipidana akan diberikan kesempatan untuk memperoleh pendidikan dan pengajaran dalam rangka pengembangan pribadinya dan tingkat kecerdasannya sesuai dengan minat dan bakat yang dijelaskan dalam Undang-Undang Nomor 35 Tahun 2014 Pasal 9 ayat (1) Tentang Perlindungan Anak. 
2. Perlindungan hukum terhadap anak sedagai korban penyalahgunaan narkoba yaitu adanya pendampingan khusus dari orang tua dan penasehat hukum saat proses pemeriksaan sampai dengan proses persidangan berlangsung. Serta hak anak yang menggunakan narkoba berupa rehabilitasi medis maupun sosial, hal ini dilakukan guna untuk penyembuhan anak secara keseluruhan dan bebas dari narkoba. Telah diatur dalam Undang-Undang Nomor 35 Tahun 2009 Tentang Narkotika. Adapun tempat rehabilitasi medis di Kabupaten Bone yaitu di RS. Hapsah Watampone, bagi anak yang hanya melakukan rehab jalan serta wajib lapor di lakukan di BNN Watampone, pengguna narkoba yang di kategorikan sebagai pecandu akan di rehab di Balai Rehabilitasi BNN Baddoka Makassar.

\section{REFERENSI}

Abdullah K. Tahapan dan Langkah-langkah dalam Penelitian. Cet. I; Watampone: Lukman Al Hakim Press, 2013.

Ali, Zainuddin, Metode Penelitian Hukum. Ed. 1 Cet.V; Jakarta: Sinar Grafika, 2014

Amir. "BAG OPS di Kepolisian Resort Bone”, wawancara oleh penulis diurbin Obs Polres Bone, 18 Juli 2018

Arikunto, Suharsimi. Prosedur Penelitian Suatu Pendekatan Praktek. Ed. Revisi Cet. XII; Jakarta: PT Rineka Cipta, 2002.

Astuti, Nurhayati Puji."pengertian-anak-menurut-ahli-dan-who",dalam http://www. gudang pengertian.com/ pengertian-anak-menurut-ahli-dan-who/ html. 13 oktober 2017.

Bungin, Burhan. Metode Penelitian Kualitatif. Cet. VIII; Jakarta: Raja Grafindo, 2011.

Darmawangsa, Baso, "Urgensi Pendidikan Islam Dalam Mengantisipasi Bahanya Penyalangunaan Narkoba Terhadap Kehidupan Anak Di Kecamatan Tempe Kabupaten Wajo", Skripsi, Program Sarjana Sekolah Tinggi Agama Islam Negeri, Watampone, 2008.

Departemen Pendidikan Nasional. Kamus Besar Bahasa Indonesia. Cet. III; Jakarta: Balai Pustaka, 2005.

Djamil, M. Nasir. Anak Bukan Untuk Dihukum. Cet. II; Jakarta: Sinar Grafika, 2013. 
Dwiyanto, Arya. "Hasil wawancara administrasi Urbin Obs Sat Res Narkoba Polres Bone”, wawancara oleh penulis di urbin Obs Res Narkoba Polres Bone 31 Juli 2018.

Faudy, Munir dan Sylvia Laura L. Faudy, Hak asasi tersangka pidana . Cet. 1; Jakarta: Prenada Media Group, 2015.

Ghoodse, Menurut. "Pengertian Narkoba Menurut Para Ahli,dalam https://materi pengetahuan umum. blogspot.co.id pengertian narkoba menurut para ahli/ htm. 13 oktober 2017.

Hasan, Muhammad Tholchah, dkk. Metode Penelitian Kualitatif Tinjauan Teoritis dan Praktis. Cet. III; Surabaya: Visipress Media, 2009.

Joewana, satya. Pencegahan dan Penanggulangan Penyalahgunaan Narkoba. Cet.I; Jakarta: Balai Pustaka, 2006.

Keri, Ismail. Metodologi Penelitian dan Penulisan Karya Ilmiah. [t. c]; [t. tp]: Unit Jurnal dan Penerbitan STAIN Watampone, 2017.

Labaruna, Ilham. "penyedik pembantu Bintara SatuanReserse Narkoba Polres Bone" wawancara oleh penulis diruangan penyidik SAT RES Narkoa polres Bone, 14 juli 2018.

M.R.,"anak penyalahguna narkoba", wawancara oleh penulis dirumah pelaku, $20 \mathrm{Juli}$ 2018.

Martino, Lydya Harlina \& satya Joewana, Pencegahan dan Penanggulangan Penyalahgunaan Narkoba. Cet.I; Jakarta: Balai Pustaka, 2006.

Martono, Lydia Harliina. Satya joewana, Membantu Pemulihan Pecandu Narkoba dan Keluarganya. Cet. I; Jakarta: Balai Pustaka, 2005.

Martono, Nanang. Metode Penelitian Sosial. Cet. I; Depok: PT Raja Grafindo Persada,2015.

Masjaya. Andi, "Dikutip dari hasil wawancara Staf Balai Pemasyarakatan Kabupaten Bone", wawancara oleh penulis di kantor Balai Pemasyarakatan Kabupaten Bone, 28 desember 2017.

Muhajir, As'aril. Ilmu Pendidikan Perspektif Kontekstual. Cet. III; Jogjakarta: Ar-ruzz Media, 2016.

Muskifa, "Upanya Pemerintah Dalam Menangulangi Tindak Pidana Narkoba Analisis Hukum Terhadap Pelaksanaan Undang-Undang Nomor 35 Tahun 2009 Tentang Narkoba", Skripsi, Program Sarjana Sekolah Tinggi Agama Islam Negeri, Watampone, 2013.

Nawawi, Syahruddin. Penelitian Hukum Normatif Versus Penelitian Hukum Normatif. Cet. II; Makassar: PT Umotoha Ukhuwah Grafika, 2014.

Noor, Juliansyah. Metodologi Penelitian. Cet. IV; Jakarta: Kencana, 2014.

Pahrum, Andri Saputra. "Kasubag Pendaftaran Sim Kepolisian Resort Bone" wawancara oleh penulis diunit Sim Lantas , 17 juli 2018.

Prasetyo, Teguh. Hukum Pidana. Cet. VI; Jakarta: Rajawali Pers, 2015 
Republik Indonesi, Undang-Undang RI Nomor 11 Tahun 2012 tentang Sistem Peradilan Pidana Anak

Republik Indonesia, "Undang-Undang RI Nomor 23 Tahun 2002 Tentang Perlindungan Anak”. Cet, II; Jakarta Redaksi Sinar Grafika, 2003.

Republik Indonesia, Undang-Undang RI Nomor 35 Tahun 2009 Tentang Narkotika.

Republik Indonesia, Undang-Undang RI Nomor 35 Tahun 2014 tentang Perlindungan Anak.

Republik Indonesia, Undang-Undang RI Nomor. 35 Tahun 2009 Tentang Narkotika. Badan Narkotika Nasional: 2011

Sahude, Muharram. "ketua Badan Narkotika Nasional”, wawancara oleh penulis di ruangan kepala BNN Kabupaten Bone11 Desember 2017.

samad, M. Yarham. "Search Skripsi Lengkap Pidana", dalam https://www.google.co.id/search skripsi lengkap pidana. 13 Oktober 2017.

samad, M. Yarham. "Search Skripsi Lengkap Pidana”, dalam https://www.google.co.id/search skripsi lengkap pidana. 13 Oktober 2017. 